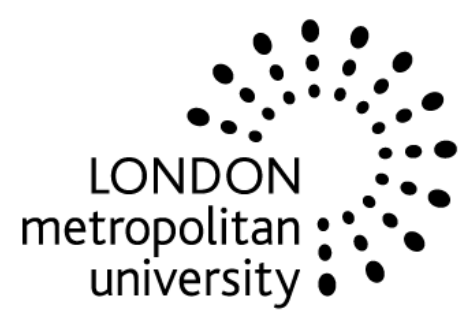

Centre for International Capital Markets

Discussion Papers

ISSN 1749-3412

The Efficiency of the Turkish Banking System

Roman Matousek, Selim Dasci and Bruno S. Sergi

No 2008-8 


\title{
The Efficiency of the Turkish Banking System
}

\author{
Roman Matousek \\ Selim Dasci \\ Bruno S. Sergi
}

April 2008

Corresponding author: Roman Matousek is Principal Lecturer in International Banking, Centre for International Capital Markets, London Metropolitan Business School, London Metropolitan University, 84 Moorgate, London EC2M 6SQ. E-mail: r.matousek@1ondonmet.ac.uk

Selim Dasci obtained his MSc degree in International Banking and Finance from London Metropolitan University and his main area of professional interest is Financial Stability in Emerging Markets.

Bruno S. Sergi teaches International Economics at the University of Messina. He has taught international classes and has been guest lecturer and adjunct professor at central banks' research departments and universities worldwide. He is the author of a number of books on transition economics and global business. 


\begin{abstract}
This study analyses the efficiency of the Turkish bank system over the period 2000-2005. The estimation shows that inefficiency decreases over the period under consideration and the analysis unambiguously indicates that the Turkish banking system has a large potential for improvement. The state banks appear to reduce their costs more comfortably than the private banks. The results also suggest that the restructuring programme that started in 2001 appears to have transformed the state-banks into the more efficient and profitable institutions.
\end{abstract}

JEL classification: $\mathrm{C} 30, \mathrm{G} 21, \mathrm{P} 20$

Keywords: Cost efficiency, banks, Turkish Banks 


\section{Introduction}

The Turkish banking sector has undergone very turbulent periods during the past two decades. The banking system was strictly regulated through licensing policy and interest rates control. While such environment contributed to a certain degree of stability within the system, it has deteriorated competitiveness and efficiency of the system as a whole. In the early 1980s the banking sector witnessed a process of gradual liberalisation. As a result domestic commercial banks started improving their efficiency in order to withstand intense competition pressures from foreign banks and rapid financial deregulation. Indeed, deregulation process that aimed at the removal of a protective umbrella played an integral part in enhancing the efficiency of the Turkish domestic banks.

Unfortunately, the stability and efficiency of the Turkish system was considerably undermined during the crisis years of 2001-2002. Since the banking sector is a backbone of the Turkish economy, the Government realised that a sound and efficient banking sector requires establishing not only macro but also micro economic environment, which will be consistent with, and help promote, the widening financial activities of commercial banks. In May 2001, the Turkish government launched so-called Rehabilitation Programme. ${ }^{1}$ The programme addressed the following priorities. Firstly, it sought to restructure three large state-owned commercial banks. Secondly, to restructure those banks that were taken over by the Savings and Deposits Insurance Fund. Further, to strengthen the financial position of private banks and last but not least important issue was also to improve the regulatory

\footnotetext{
1 This restructuring process was similar to those restructuring programmes set up in
} Central and East Europe (see e.g. Matousek and Sergi 2005; Matousek and Taci, 2004). 
and supervisory framework. The authorities set the basic regulatory and supervisory framework, new operational guidelines and principles for banks' prudential behaviour.

The paper carries out an analysis of banking systems and estimates the cost efficiency concept by applying the methodological model developed by Battese and Coelli $(1992,1995)$. Also, the paper contributes to policy makers and bank management by outlying alternative strategies of how to mitigate potential inefficiency of commercial banks. Further, it provides with policy recommendations for those economies that still face significant challenges in banking consolidation. In addition, recent empirical studies have not covered the period after the crisis, i.e., 2000-2005. The analysis tries to identify actual or potential problems in banking systems and individual banks. Such information is valuable in the process of further banking consolidation and restructuring but also in discussions about the competitiveness and efficiency of the Turkish banking sector in the context of the EU enlargement process. If there is significant inefficiency among banks there may be room for further structural changes, increased competition, mergers and acquisitions.

The imposed working hypotheses are based on assumptions that the rapid and successful restructuring of banking sectors should be reflected in higher efficiency. Foreign banks should presumably show higher efficiency compared to domestic banks (Isik and Hassan, 2002); Mercan and Yolalan, 2000). At the same time, small and medium sized banks should be on average more efficient than large banks.

The paper is structured as follows. Section 2 reviews current studies on the frontier cost function applied in developed and developing economies. A further section tackles the methodological concept of estimating cost efficiency in the banking industry. 
Section 4 discusses results. Section 5 concludes and provides with policy recommendations.

\section{Literature Review}

There has been extensive research in applying the frontier efficiency analysis in the banking industry. Bauer et al. (1993), Berger (1993), Berger and Humprey (1997), and Hunter and Timme (1995), to mention only few, perform efficiency studies on the U.S. banking sector. Molyneux et al. (1996) provide a comprehensive overview of the research on banking efficiency for European banks. Using the Fourier-flexible functional form and stochastic cost frontier methodologies, Carbo et al. (2002) estimate the efficiency of savings banks in the European Union market. Drake and Hall (2003) apply the non-parametric frontier approach, data envelopment analysis, for estimating technical and scale efficiency in Japanese banking.

Empirical research on the efficiency of commercial banks in Turkey has been rather limited. Zaim (1995) and Ertugrul and Zaim (1999) investigate the impact of financial liberalization on the efficiency of Turkish banking using the data envelopment Analysis (DEA) and find positive effect on efficiency. Denizer et al. (2000) examine the efficiency of Turkish commercial banks in a pre and post-liberalization environment using the DEA approach and find that liberalization programmes were followed by an observable decline in efficiency. Mercan and Yolalan (2000) provide a survey of studies focusing on the efficiency of the Turkish banking system.

Isik and Hassan (2002) employed a non-parametric approach along with a parametric approach to estimate the efficiency of Turkish banks over the period 19881996. The estimated results show that main source of inefficiency in Turkish banking is 
due to technical inefficiency rather than allocative inefficiency. They also discussed that foreign banks operating in Turkey are significantly more efficient than their domestic peers.

Kasman (2002) used a three input - three output Fourier-flexible cost function specification to investigate cost efficiency, scale economies, and technological progress in the Turkish banking system over the period 1988-1998. Empirical results disclosed that the Turkish banking system had a significant inefficiency problem in the analysed period. Although the annual inefficiency average decreased over the sample period, Kasman asserts that commercial banks in the sector operated more inefficiently than their U.S. and European counterparts. The results also suggested the existence of significant economies of scale across the sample and no evidence of diseconomies of scale for larger banks was identified.

\section{Data and Model Specification}

In our analysis, we use annual panel data over the period 2000-2005 for each of the three state-owned and twenty private commercial banks, listed in Appendix Table 1. The source of our database is from the Banks Association of Turkey and Turkish Government Information Centre.

Our sample includes 23 commercial banks operating in Turkey and controlling 98.8 per cent of total banks assets. The sample thus reflects almost the entire population of the commercial banks in Turkey and is superior to BankScope database. Table 1 displays the summary statistics for all variables used in the cost function. The cost 
efficiency of Turkish commercial banks is estimated by using the programme Frontier $4.1^{2}$

Different techniques have been developed in the literature to measure firms' cost or production efficiency. The difference between these techniques reflects underlying assumptions used in estimating the frontiers. Berger and Mester (1997) provide a comprehensive survey of the differences in efficient concepts and methods as applied to the banking industry.

Measurement of bank efficiency is generally conducted within the framework of measurements of $X$-inefficiency. Assuming that there is a common efficiency frontier, the deviation of a bank from that frontier is a measure of $X$-inefficiency. Under the cost frontier specification, the actual cost increased in producing a particular bundle of outputs is compared to the minimum cost necessary for production of the same bundle. Xinefficiency is then measured as the deviation from this minimum cost. The cost frontier is formulated by estimating a cost function, which relates observed cost to output quantities and input prices, allowing for random error and inefficiency. This estimate of cost inefficiency includes both, technical inefficiency, defined as the use of too much input to produce a given output, and allocative inefficiency, defined as the use of suboptimal proportions of each of inputs given the prevailing market prices (Matousek and Taci, 2004).

Following Hunter and Timme (1995), the error term for bank $i$ at time $t$ can be expressed as

\footnotetext{
${ }^{2}$ FRONTIER 4.1 programme calculates the maximum likelihood estimates of a wide variety of stochastic frontier models.
} 
$\varepsilon_{\mathrm{i}, \mathrm{t}}=\ln \left(\mathrm{v}_{\mathrm{i}, \mathrm{t}}\right)+\ln \left(\mathrm{u}_{\mathrm{i}}\right)$

where $\ln \left(\mathrm{v}_{\mathrm{i}, \mathrm{t}}\right)$ is a random error component that varies with time and is distributed with a zero mean over time, and $\ln \left(u_{i}\right)$ is a time-independent measure of efficiency of a bank. In order to be consistent with this error-term specification, the cost function can then be expressed with a residual in multiplicative form

$$
\operatorname{Cost}_{i, t}=C_{t}\left(q_{i, t}, y_{i, t}\right) v_{i, t} u_{i}
$$

Where $\mathrm{C}_{\mathrm{t}}$ is a cost function and $\mathrm{q}_{\mathrm{i}, \mathrm{t}}$ and $\mathrm{y}_{\mathrm{i}, \mathrm{t}}$ are outputs and input prices, respectively. This cost function in logarithm is

$$
\ln \operatorname{Cost}_{\mathrm{i}, \mathrm{t}}=\ln \mathrm{C}_{\mathrm{t}}\left(\mathrm{q}_{\mathrm{i}, \mathrm{t}}, \mathrm{y}_{\mathrm{i}, \mathrm{t}}\right)+\ln \left(\mathrm{v}_{\mathrm{i}, \mathrm{t}}\right)+\ln \left(\mathrm{u}_{\mathrm{i}}\right)
$$

The term $\ln \left(\mathrm{u}_{\mathrm{i}}\right)$ is assumed to be orthogonal to the regressors in the cost function. The error term $\varepsilon_{\mathrm{i}, \mathrm{t}}$ is to be estimated for each bank and each year. In this way, the parameters in the cost function and the random error term $\ln \left(\mathrm{v}_{\mathrm{i}, \mathrm{t}}\right)$ are allowed to change for each year while $\ln \left(\mathrm{u}_{\mathrm{i}}\right)$ remains constant over time. As pointed out by Battese and Coelli (1998), the independence assumption of $v_{i t}$ and $u_{i t}$ is improbable, other things being equal. One expects that efficient banks remain reasonably efficient from period to period, and inefficient banks improve their efficiency levels over time.

In our study, Battese and Coelli (1992) model - Time-Varying Inefficiency (Model 1) - is applied. This model determines behaviour of banks inefficiencies. The model takes the following form: 
$u_{i t}=f(t) * u_{i}$

where $f(T)=1$ is a function that determines how technical inefficiency varies over time:

$u_{i t}=u_{i} * \exp \{\eta(t-T)\} \quad \mathrm{i}=1,2, \ldots, \mathrm{N} \quad \mathrm{t}=1,2, \ldots, \mathrm{T}$

where $\eta$ is an unknown parameter to be estimated.

The model can be estimated under the assumption that $u_{i}$ has a truncated normal distribution: $u_{i} \square i i d N^{+}\left(\mu, \sigma_{u}^{2}\right)$

The second model that we estimate is based on Battese and Coelli (1995) concept of Time-Invariant Inefficiency Concept by including Environmental Variables (Model 2). The ability of a manager to convert inputs into outputs or to minimize the cost of the operations is often influenced by exogenous variables that characterize the environment in which production takes place, for example, regulation, ownership structure, unpredictable stochastic variables that can be regarded as sources production risk.

Battese and Coelli $(1993,1995)$ generalized the model developed by Kumbhakar et al. (1991) by using panel data. To investigate factors causing variations in inefficiencies among banks and across time Battese and Coelli (1995) propose the following specification of the term of inefficiency: 
$u_{i t}=z_{i t} * \delta+M_{i t}$

where the random variable, $M_{i t}$, are defined by the truncated normal distribution with mean zero and variance $\sigma_{u}^{2}$, so that the point of truncation becomes $-z_{i t} * \delta$, from where $M_{i t} \geq-z_{i t} * \delta$. Thus, distribution of the random term $\mathrm{u}_{\mathrm{I}}$ relating to the measurement of the inefficiency will be that of a truncated normal distribution of variance $\sigma_{u}^{2}$ and expectation $\mathrm{B}_{\mathrm{it}}$ expressed as (Coelli et al, 2005):

$\mathrm{B}_{\mathrm{it}}=z_{i t} * \delta$

Where $\delta$ is a vector of $p$ parameters to estimate, and $z_{i t}$ is a vector of $p$ variables which can affect a bank efficiency (Bouchaddakh and Salah, 2005). A standard second order, non-homothetic translog approximation to the multiproduct total cost function is taken for estimation.

The cost function can be written as

$$
\begin{aligned}
& \ln T C_{t}=\alpha_{0}+\sum_{m} \alpha_{m} \ln y_{m, t}+1 / 2 \sum_{m} \sum_{n} \alpha_{m, n} \ln y_{m, t} \ln y_{n, t}+\sum_{i} \beta_{i} \ln q_{i, t}+ \\
& 1 / 2 \sum_{i} \sum_{j} \beta_{i, j} \ln q_{i, t} \ln q_{j, t}+\sum_{i} \sum_{m} \phi_{i, m} \ln q_{i, t} \ln y_{m, t}+\sum_{i} \gamma_{i} \text { Ownership }_{i}+\sum_{i} \delta_{i} \text { Size }_{i}+\varepsilon_{i, t}
\end{aligned}
$$

where TC is total cost, $\ln y_{m, t}$ vector of inputs and $\ln q_{i, t}$ outputs. Two dummy variables are added ownership (OWN) and bank's size (SIZE) to asses whether differences in ownership structure and/or the size of the bank influence the cost efficiency. OWN is an 
ownership dummy, state-owned banks have value one and private banks zero. SIZE is a size dummy, banks with assets more than \$US 10.000 millions have the value one and banks below this volume zero.

In the literature there are two approaches - production and intermediation - to measure bank outputs and costs (Berger, Hanwek and Humphrey, 1987). We apply the intermediation approach. A competitive and thus efficient firm would minimise the total of operating and interest costs for any given output. To determine which bank products to include as outputs we employed the criterion of value added. Banking functions that produce a flow of banking services associated with a substantial labour or physical capital expenditure are identified as outputs. Table 1 provides a list of variables that are used in the analysis.

Total costs (C) that is defined as operating costs plus interest costs, including cost of funds, fixed assets, and labour. Total loans $\left(\mathrm{y}_{1}\right)$ are defined as short-term loans plus medium and long-term loans and impaired loans, excludes loan loss reserves. Total earning assets $\left(\mathrm{y}_{2}\right)$ include short-term investment, trading securities, securities held under REPO agreement, long-term investment and non-interest income, while excluding investment loss reserves. Price of labour $\left(\mathrm{w}_{1}\right)$ is defined as the ratio of total expenses on employees to the number of employees. Price of financial capital $\left(\mathrm{w}_{2}\right)$ is calculated as the ratio of total interest expenses on borrowed funds to total borrowed funds.

Total interest expenses on borrowed funds include interest paid on total deposits plus interest paid on interbank borrowing. Total borrowed funds include total deposits, borrowing from central bank, deposits from banks, borrowing from banks, borrowing from non-bank financial institutions, deposits against other credit facilities, bonds issued, 
and long-term borrowing. Price of physical capital $\left(\mathrm{w}_{3}\right)$ : the ratio of total expenses on the fixed assets to total fixed assets. Total fixed assets are calculated as gross fixed assets less depreciation. Total expenses on the fixed assets are defined as operating expenses minus expenses on employees.

\section{Empirical Results}

Table 2 displays the estimated coefficients of our Model 1. As can be seen, the estimated value of gamma is 0.14 , which indicates that 14 percent of the variation in the composite error term is due to the inefficiency component. $\eta$ then captures the time component of inefficiency. The estimated value is positive and significant at 5 percent level. This supports our hypothesis that inefficiencies of banks had been falling over time. In other words, the cost efficiency has improved over the analysed period. This applies to all banks since the parameter $\eta$ is time-invariant in terms of ordering of banking firms' inefficiencies (Coelli, 1992).

Table 3 shows the estimated mean efficiencies of individual banks. This Table also provides summary of the Turkish banking system during 2004-2005. The average efficiency rate varies from 75.6 per cent to 88.8 per cent between 2000 and 2005 . In other words, mean efficiency was 82.8 per cent for the sample period which means that the Turkish commercial banks used only 82.8 per cent of available resources over the period 2000-2005. Analysing the mean efficiency according to the ownership structure one gets more detailed views on efficiency within the Turkish banking system. The state-owned commercial banks exhibits highest efficiency score compared to private banks and foreign banks. As for the state-banks their efficiency ranges from 83.6 per cent in 2000 to 
92.8 per cent in 2005 . The overall efficiency scores are 88.63 per cent for the state banks, 82.07 per cent for the private banks and 81.15 per cent for the foreign-owned banks.

Table 4 shows that the overall mean score is 82.80 percent for the whole sample, the state banks seem to be operating more cost efficient than both private and foreign banks. The private banks' mean efficiency is similar to the overall efficiency score while foreign banks seem to be operating slightly below the overall mean efficiency average.

The mean efficiency for the banking system as a whole as well as of each group, shows an increasing trend which is indicated by the positive sign of $\eta$. In our estimation $\eta$ is 0.17 .

It is important to stress that the ranking of the banks is constrained, i.e. it is same in each year, though their efficiency scores can vary over the years (Battese and Coelli, 1992). Our sample contains twenty three banks. Sixteen of them are domestic private banks, three state banks and four foreign banks. The estimated model indicates that state banks are more efficient than the private banks. The high variation of inefficiency across the tested sample is rather surprising. The efficiency scores of the top three banks namely the ABN Amro bank (foreign), the Ziraat bank (state) and Halk Bank (state) with efficiency scores of 94.7 per cent, 94.2 per cent and 94 per cent respectively are much higher compared to that of the lowest three banks namely Sekerbank (private), Turkish bank (private) and Citibank (foreign).

The highest efficiency of state banks may be explained by the fact that larger banks tend to be more efficient because of superior managerial skills and expertise. In the case of Turkish state banks, this argument holds since two state banks are large banks in terms of total asset and the number of branches. Furthermore, the price of labour is relatively 
low in the state banks compared to the relatively high labour cost in the private and foreign banks. In addition, state-banks are likely to be less cost effective because they are expected to meet social welfare goals and subject to "soft" budget constraints. By contrast, even though the state is a key shareholder in the state banks, they have been subject to relatively "hard" budget constraints.

Model 2 enables us to analyse the impact of ownership structure, size and deregulation on operational banks efficiency. Different banks and bank groups can react differently to these factors the rankings in terms of efficiency can be reasonably expected to change.

Table 5 presents the estimated coefficients and the associated t-ratios respectively, of the translog cost function specified in Model 2. Two dummy variables are added OWN and SIZE respectively, to asses whether differences in ownership structure and/or the size of the bank influence the cost efficiency.

LR statistics reconfirms that the stochastic frontier specification is the appropriate method to assess the bank performance. The LR statistics is significant at the 5 per cent level. In Battese and Coelli (1995) specification, the null hypothesis of the absence of bank specific inefficiencies translates into $\mathrm{H}_{0}: \gamma=\delta_{0}=\delta_{1 \ldots \ldots . .} \delta_{m}=0$, where $\delta$ 's are the parameters associated with the $\mathrm{z}$ variables (Coelli,1996).

The estimated value of $\gamma$ is higher in Model 2 than the in Model 1. That means that much of the variation in the composite error term is due to the inefficiency component in Model 2. However, there are other important factors (reforms, government intervention etc.) that influences the unconditional variance of the one-sided error term. 
Model 2 indicates that state banks appeared to be less cost efficient than private and foreign banks as suggested by Model 1 . The estimated SIZE dummy is negative and statistically significant implying that large banks with significant asset holdings appear to be less cost inefficient than relatively small banks. In our results with the exception of ABN Amro Bank, the banks with the large asset size and branch numbers come out to be more efficient than relatively small-size banks in the Turkish banking industry. The ownership dummy is negative but statistically insignificant implying that the cost efficiency is due to asset size rather than the ownership structure in the industry.

Table 6 provides the ranking of the banks according to their overall mean cost efficiency over the sample period 2000-2005. Within all banks, the efficiency scores of the top three banks namely the Halk bank (state), the Ziraat bank (state) and Halk Bank (state) with efficiency scores of 97.1 per cent, 96.6 per cent and 95.3 per cent respectively are much higher compared to that of the lowest three banks namely Tekfenbank (private), Turkish bank (private) and Citibank (foreign) (efficiency scores of 72.7 per cent, 66.9 per cent and 61.8 per cent respectively).

The efficiency scores gap is significantly large between top private banks, namely Is bank and Oyak showing efficiency scores of 93.1 per cent and 93 per cent respectively and the lowest efficiency of private banks Tekfenbank and Turkish bank (efficiency scores of 72.7 per cent and 66.9 per cent respectively). Within the group of state banks, the variation in efficiency score is very slight; however, there are only three state banks in the sample.

Halk bank (state) comes out to be the more efficient bank operating in Turkey compared to the all banks in the sample according to the Model 2 which occupies the 
third spot in Model 1. The estimated average efficiencies by applying Model 2 are higher than those in Model 1 due to the fact that Model 2 takes the determinants of inefficiency into account explicitly. The state banks are more cost efficient compared to private banks in Turkey may be surprising. This result implies that the banking crises affected the private banking sector more than state banks.

However, the Banking Sector Restructuring Programme that was introduced as a reaction to financial crises in November 2000 and February 2001, helped to improve efficiency of state banks. The state banks appear to have benefited from the restructuring programme more than private and foreign banks.

Furthermore, number of branches of the state banks, which was 2,494 as of December 2000, was brought down to 2,110 as of December 2005; and the number of personnel, which was 61,601 , was reduced to 38,037 .

The restructured state banks with the advantage of low personnel costs and cheaper cost of borrowing funds, particularly ,deposits over private banks appear be more cost efficient .They use their large size and vast branch numbers especially located in rural parts of Turkey to obtain deposits to reduce their cost price if funds.

\section{Conclusions}

The study analysed the efficiency of the Turkish banks over the period 2000-2005 and our estimation showed that inefficiency decreased over the sample period. Furthermore, the analysis unambiguously indicates that the Turkish banking system has a large potential for improvement. For example, the mean cost efficiency of the banking 
industry over the sample period is 82.80 per cent, that is, banks operating under the best practices would have used only 82.8 per cent of their inputs. In addition, we estimated cost efficiencies separately in order to assess whether the type of ownership structure has an impact on the level of efficiency. We showed that the state banks are among best banks that may be partly explained by the restructuring programme. Private banks seem to be recovering after the recent banking crises although rather slower than the state banks. In fact, the state banks appear to be able to reduce their costs more comfortably than the private banks by using their size, their low employee expenses and less expensive cost of borrowing. Moreover, the main borrowing method for the banks in Turkey is deposits and state banks seem to benefit from their extensive branch network reaching to the rural areas of Turkey far easier than private banks.

However, there are still significant inefficiencies in the Turkish banking system and further improvements are needed to increase their efficiency, profitability and competitiveness in order the Turkish banking system is fully integrated into international markets. 


\section{References}

Berger, A.N., and Humphrey, D.B. (1997). Efficiency of Financial Institutions: International Survey and Directions for Future Research. European Journal of Operational Research 98, pp.175-212.

Berger, A.N., and Mester, L.J. (1997). Inside the Black Box: What Explains Differences in Efficiencies of Financial Institutions. Journal of Banking and Finance 21, pp.895-947.

Berger, A.N., Hunter, W.C., and Timme, S.G. (1993). The Efficiency of Financial Institutions: A Review and Preview of Research Past, Present and Future. Journal of Banking and Finance 17, pp.221-249.

Carbo, S., Gardener, E.P.M., and Williams, J. (2002). Efficiency in Banking: Empirical Evidence from the Savings Bank Sector. The Manchester School 70, pp.204-228.

Denizer, C. (2000). Foreign Entry in Turkey's Banking Sector, 1980-1997. World Bank Policy Research Working paper No. 2462.

Drake, L., and Hall, M.J.B. (2003). Efficiency in Japanese Banking: An Empirical Analysis. Journal of Banking and Finance 27, pp.891-917.

Ertugrul, A., Zaim, O. (1999). Economic Crises and Efficiency in Turkish Banking Industry. METU Studies in Development, 26(1-2), pp 99-116.

Goddard, J.A., Molyneux, P., and Wilson, O.S. (2001). European Banking: Efficiency, Technology and Growth. London: John Wiley \& Son.

Greene, W.H. (1999). Frontier Production Function. In M.H., Pesaran and P., Schmidt (eds) Handbook of Applied Econometrics, Volume II: Microeconomics. Oxford: Blackwell.

Hasan, I., and Marton, K. (2003). Development and Efficiency of the Banking Sector in a Transitional Economy; Hungarian Experience. Journal of Banking and Finance 27, pp.2249-2271.

Hunter, W.C., and Timme, S.G. (1995). Core Deposits and Physical Capital: A Reexamination of Bank Scale Economies and Efficiency with Quasi-Fixed Inputs. Journal of Money, Credit and Banking, XXVII, pp.165-185.

Isik, I., Hassan, M.K. (2002). Technical, Scale and Allocative Efficiencies of Turkish Banking Industry. Journal of Banking and Finance, Vol. 26 No.4, pp.719-766.

Kasman, A. (2002). Cost Efficiency, Scale Economies, and Technological Progress in Turkish Banking. Central Bank Review 1, pp.1-20. 
Leibenstein, H. (1966). Allocative Efficiency vs. "X-Efficiency". American Economic Review 54, pp.392-415.

Matousek, R, and Sergi, B.S. (2005). Managing Non-Performing Loans in Transition: Czech Republic, Hungary, and Poland. Journal of East West Business, 11,(1\&2), pp.141166.

Matousek, R., and Taci, A. (2004). Efficiency in Banking: Empirical Evidence from the Czech Republic. Economics of Planning, 37, pp.225 -244.

Mercan, M., Yolalan, R. (2000). The Effect of Scale and Mode of Ownership on the Turkish Banking Sector Financial Performance. The ISE Review vol. 4 No.15, pp.2-23.

Mester, L.J. (1996). A Study of Bank Efficiency Taking into Account Risk Preferences. Journal of Banking and Finance 17, pp.267-286.

Zaim,O. (2003). The effect of financial liberalization on the efficiency of Turkish Commercial Banks. Applied Financial Economics 5, pp. 257-264. 
Table 1.Variables Used to Estimate Cost Efficiency (million SUSD)

\begin{tabular}{|c|c|c|c|c|c|c|}
\hline Variable & Description & Mean & Median & St.Dev. & Min. & Max. \\
\hline $\mathrm{C}$ & Total costs & 1143.181 & 450.5 & 1594.784 & 14 & 8836 \\
\hline Y1 & Total loans & 2216.638 & 839.5 & 3029.812 & 4 & 16475 \\
\hline Y2 & Total earning assets & 2783.13 & 651 & 5184.251 & 11 & 30444 \\
\hline W1 & Price of labour & 0.026908 & 0.024037 & 0.017945 & 0.003841 & 0.125001 \\
\hline W2 & Price of financial capital & 0.143347 & 0.116228 & 0.090721 & 0.054332 & 0.709115 \\
\hline W3 & Price of physical capital & 1.574603 & 1.179815 & 1.761873 & 0.080519 & 13 \\
\hline Z & Total assets & 7272.413 & 2469 & 9908.137 & 58 & 48480 \\
\hline
\end{tabular}


Table 2 Estimates for Time-Varying Inefficiency — Model 1

\begin{tabular}{|c|c|c|c|c|}
\hline Ind.Variab. & Description & Par. & Coefficient & T-ratio \\
\hline Constant & & $\beta_{0}$ & -2.1451 & -2.2213 \\
\hline $\operatorname{Ln}_{1}$ & Total loans & $\beta 1$ & -0.7155 & -1.7993 \\
\hline $\operatorname{Ln~}_{2}$ & Total earning assets & $\beta 2$ & -0.3651 & -0.8068 \\
\hline $\operatorname{Ln~w}_{1}$ & Price of labour & $\beta 3$ & -0.7431 & -1.1825 \\
\hline Ln w2 & Price of financial capital & $\beta 4$ & 0.2658 & 0.6708 \\
\hline Ln w3 & Price of physical capital & $\beta 5$ & 0.5037 & 1.6258 \\
\hline Ln y1 ln y $1 / 2$ & Total loans * Total loans $/ 2$ & $\beta 6$ & -0.1159 & -0.984 \\
\hline Ln y1 ln y2 & Total loans * Total earning assets & $\beta 7$ & -0.0347 & -0.6759 \\
\hline Ln y1 ln w1 & Total loans * Price of labour & $\beta 8$ & -0.0868 & -0.7545 \\
\hline Ln y1 ln w2 & Total loans * Price of financial capital & $\beta 9$ & -0.1805 & -2.1419 \\
\hline Ln y1 ln w3 & Total loans * Price of physical capital & $\beta 10$ & 0.1789 & 3.5104 \\
\hline $\operatorname{Ln} y 2 \ln y 2 / 2$ & Total earning assets $*$ Total earning assets $/ 2$ & $\beta 11$ & 0.02159 & 0.3942 \\
\hline Ln y2 ln w1 & Total earning assets $*$ Price of labour & $\beta 12$ & -0.0783 & -0.6885 \\
\hline Ln y2 lnw2 & Total earning assets * Price of financial capital & $\beta 13$ & -0.0964 & -1.507 \\
\hline Ln y2 ln w3 & Total earning assets * Price of physical capital & $\beta 14$ & 0.0762 & 2.0936 \\
\hline Ln w1 ln w1 /2 & Price of labour * Price of labour $/ 2$ & $\beta 15$ & -0.114 & -0.4431 \\
\hline Ln w1 ln w2 & Price of labour * Price of financial capital & $\beta 16$ & 0.02672 & 0.1667 \\
\hline Ln w1 ln w3 & Price of labour * Price of physical capital & $\beta 17$ & 0.008267 & 0.09878 \\
\hline Ln w2 $\ln w 2 / 2$ & Price of financial capital $*$ Price of financial capital $/ 2$ & $\beta 18$ & 0.05611 & 0.41009 \\
\hline Ln w2 ln w3 & Price of financial capital * Price of physical capital & $\beta 19$ & 0.05444 & 0.9283 \\
\hline Ln w3 $\ln w 3 / 2$ & Price of physical capital * Price of physical capital $/ 2$ & $\beta 20$ & -0.05618 & -1.7335 \\
\hline \multirow[t]{6}{*}{ Model 1} & $\sigma^{2}$ & & 0.02257 & 5.8823 \\
\hline & $\gamma$ & & 0.1478 & 1.2671 \\
\hline & $\mu$ & & 0.1155 & 1.129026 \\
\hline & $\eta$ & & 0.1728 & 1.9805 \\
\hline & Log-likelihood & & 62.0747 & \\
\hline & LR test of the one-sided error & & 15.3616 & \\
\hline
\end{tabular}


Table 3: Efficiency estimates 2000 - 2005 (Model 1)

\begin{tabular}{|c|c|c|c|c|c|c|c|}
\hline Bank ID & Bank Name & 2000 & 2001 & 2002 & 2003 & 2004 & 2005 \\
\hline 1 & T.C.Ziraat Bankasi & 86.7 & 88.7 & 91.9 & 91.9 & 93.1 & 94.2 \\
\hline 2 & Turkiye Is Bankasi & 81 & 83.8 & 88.3 & 88.3 & 90.1 & 91.6 \\
\hline 3 & Akbank & 85.2 & 87.4 & 91 & 91 & 92.4 & 93.5 \\
\hline 4 & Turkiye Garanti Bankasi & 74.3 & 77.9 & 83.8 & 83.8 & 86.2 & 88.3 \\
\hline 5 & $\begin{array}{c}\text { Turkiye Vakiflar } \\
\text { Bankasi }\end{array}$ & 78.1 & 81.2 & 86.4 & 86.4 & 88.4 & 90.2 \\
\hline 6 & Turkiye Halk Bankasi & 86.1 & 88.2 & 91.5 & 91.5 & 92.9 & 94 \\
\hline 7 & Yapi ve Kredi Bankasi & 71.1 & 75 & 81.6 & 81.6 & 84.3 & 86.6 \\
\hline 8 & Kocbank & 76.8 & 80.1 & 85.5 & 85.5 & 87.6 & 89.5 \\
\hline 9 & Finansbank & 75.9 & 79.3 & 84.9 & 84.9 & 87.1 & 89.1 \\
\hline 10 & Denizbank & 77.9 & 81.1 & 86.2 & 86.2 & 88.3 & 90.1 \\
\hline 11 & Oyak Bank & 83.8 & 86.2 & 90 & 90 & 91.6 & 92.9 \\
\hline 12 & HSBC Bank & 70.7 & 74.8 & 81.4 & 81.4 & 84.1 & 86.5 \\
\hline 13 & Fortis Bank & 76.4 & 79.8 & 85.3 & 85.3 & 87.5 & 89.4 \\
\hline 14 & Turk Ekonomi Bankasi & 71.5 & 75.4 & 81.9 & 81.9 & 84.6 & 86.9 \\
\hline 15 & Sekerbank & 63.4 & 68.1 & 76.2 & 76.2 & 79.6 & 82.6 \\
\hline 16 & Citibank & 59.2 & 64.3 & 73.2 & 73.2 & 76.9 & 80.2 \\
\hline 17 & Anadolubank & 81.8 & 84.5 & 88.8 & 88.8 & 90.5 & 91.9 \\
\hline 18 & Tekstil bankasi & 70.6 & 74.7 & 81.3 & 81.3 & 84.1 & 86.4 \\
\hline 19 & Alternatif Bank & 80.6 & 83.4 & 88 & 88 & 89.8 & 91.4 \\
\hline 20 & ABN Amro Bank N.V & 87.8 & 89.7 & 92.6 & 92.6 & 93.8 & 94.7 \\
\hline 21 & Tekfenbank & 63.8 & 68.5 & 76.5 & 76.5 & 79.9 & 82.8 \\
\hline 22 & Turkish Bank & 62.6 & 67.5 & 75.7 & 75.7 & 79.2 & 82.2 \\
\hline \multirow[t]{2}{*}{23} & MNG Bank & 73.7 & 77.4 & 83.4 & 83.4 & 85.9 & 88 \\
\hline & Mean efficiency & 75.609 & 79 & 84.583 & 84.583 & 86.865 & 88.826 \\
\hline
\end{tabular}


Table 4 Banks Efficiency and Ownership Structure

\begin{tabular}{|c|cccc|}
\hline Year & All banks & State-owned & Private & Foreign \\
\hline & & & & \\
2000 & $75.60 \%$ & $83.60 \%$ & $74.60 \%$ & $73.50 \%$ \\
2001 & $79 \%$ & $86 \%$ & $78.10 \%$ & $77.10 \%$ \\
2002 & $82 \%$ & $88.10 \%$ & $81.20 \%$ & $80 \%$ \\
2003 & $84.50 \%$ & $89.90 \%$ & $83.90 \%$ & $83.10 \%$ \\
2004 & $86.80 \%$ & $91.40 \%$ & $86.30 \%$ & $85.50 \%$ \\
2005 & $88.90 \%$ & $92.80 \%$ & $88.30 \%$ & $87.70 \%$ \\
\hline mean & $\mathbf{8 2 . 8 0} \%$ & $\mathbf{8 8 . 6 3 \%}$ & $\mathbf{8 2 . 0 7 \%}$ & $\mathbf{8 1 . 1 5 \%}$ \\
\hline
\end{tabular}


Table 5 Estimates for Time-Invariant Inefficiency Concept - Model 2

\begin{tabular}{|c|c|c|c|c|}
\hline Independent Var & Description & Parameter & Coefficient & T-ratio \\
\hline constant & & $\beta_{0}$ & -6.9224 & -6.2132 \\
\hline $\operatorname{Ln} y_{1}$ & Total loans & $\beta 1$ & -1.8736 & -4.8323 \\
\hline $\operatorname{Ln} \mathrm{y}_{2}$ & Total earning assets & $\beta 2$ & -1.1586 & -2.9048 \\
\hline $\mathrm{Ln} \mathrm{w}_{1}$ & Price of labour & $\beta 3$ & -3.3964 & -4.7501 \\
\hline Ln w2 & Price of financial capital & $\beta 4$ & -1.2696 & -2.4531 \\
\hline Ln w3 & Price of physical capital & $\beta 5$ & 0.4342 & 1.6674 \\
\hline Ln y1 ln y $1 / 2$ & Total loans * Total loans $/ 2$ & $\beta 6$ & -0.2084 & -2.589 \\
\hline Ln y1 ln y2 & Total loans * Total earning assets & $\beta 7$ & -0.0538 & -0.956 \\
\hline Ln y1 ln w1 & Total loans * Price of labour & $\beta 8$ & -0.5185 & -3.761 \\
\hline Ln y1 ln w2 & Total loans * Price of financial capital & $\beta 9$ & -0.4315 & -4.5469 \\
\hline Ln y1 ln w3 & Total loans * Price of physical capital & $\beta 10$ & 0.1478 & 3.3515 \\
\hline $\operatorname{Ln} y 2 \ln y 2 / 2$ & Total earning assets $*$ Total earning assets $/ 2$ & $\beta 11$ & -0.0237 & -0.3772 \\
\hline Ln y2 ln w1 & Total earning assets $*$ Price of labour & $\beta 12$ & -0.2439 & -2.1792 \\
\hline Ln y2 lnw2 & Total earning assets * Price of financial capital & $\beta 13$ & -0.1996 & -3.3675 \\
\hline Ln y2 ln w3 & Total earning assets * Price of physical capital & $\beta 14$ & 0.1413 & 3.8842 \\
\hline Ln w1 ln w1/2 & Price of labour * Price of labour/2 & $\beta 15$ & -0.7806 & -2.8572 \\
\hline Ln w1 ln w2 & Price of labour * Price of financial capital & $\beta 16$ & -0.4464 & -2.3818 \\
\hline Ln w1 ln w3 & Price of labour * Price of physical capital & $\beta 17$ & 0.0522 & 0.6376 \\
\hline Ln w2 $\ln w 2 / 2$ & $\begin{array}{l}\text { Price of financial capital * Price of financial } \\
\text { capital } / 2\end{array}$ & $\beta 18$ & -0.3109 & -1.9573 \\
\hline Ln w2 $\ln w 3$ & $\begin{array}{l}\text { Price of financial capital * Price of physical } \\
\text { capital }\end{array}$ & $\beta 19$ & 0.0717 & 1.406 \\
\hline Ln w3 ln w3 /2 & $\begin{array}{l}\text { Price of physical capital * Price of physical } \\
\text { capital } / 2\end{array}$ & $\beta 20$ & -0.0063 & -0.7022 \\
\hline dummy & dummySIZE & delta 1 & -0.6654 & -4.5155 \\
\hline dummy & dummyOWNERSHIP & delta 2 & -2.1504 & -4.1884 \\
\hline \multirow[t]{4}{*}{ Model 2} & $\sigma^{2}$ & & 0.1209 & 4.105 \\
\hline & $\gamma$ & & 0.9738 & 46.38 \\
\hline & Log-likelihood & & 65.70 & \\
\hline & LR test of the one-sided error & & 22.61 & \\
\hline
\end{tabular}


Table 6 Efficiency estimates 2000 - 2005 (Model 2)

\begin{tabular}{|c|c|c|c|c|c|c|c|}
\hline Bank ID & Bank Name & 2000 & 2001 & 2002 & 2003 & 2004 & 2005 \\
\hline 1 & T.C.Ziraat Bankasi & 97.7 & 97.5 & 96.3 & 95.7 & 97 & 95.4 \\
\hline 2 & Turkiye Is Bankasi & 88.4 & 97.7 & 92.5 & 90.5 & 94.3 & 95.4 \\
\hline 3 & Akbank & 86.7 & 93.9 & 89.5 & 92.1 & 95.5 & 97.1 \\
\hline 4 & Turkiye Garanti Bankasi & 84.5 & 90.1 & 90.7 & 89 & 87.9 & 87.8 \\
\hline 5 & $\begin{array}{c}\text { Turkiye Vakiflar } \\
\text { Bankasi }\end{array}$ & 93.6 & 93.9 & 95.5 & 94.5 & 96.4 & 98.1 \\
\hline 6 & Turkiye Halk Bankasi & 96.2 & 96.2 & 97.2 & 97.6 & 97.7 & 97.8 \\
\hline 7 & Yapi ve Kredi Bankasi & 95.7 & 93.8 & 91.7 & 92.5 & 94 & 55 \\
\hline 8 & Kocbank & 62.8 & 82.9 & 88.2 & 88.6 & 89.9 & 97.4 \\
\hline 9 & Finansbank & 69.1 & 86 & 93.7 & 85.8 & 91.7 & 92 \\
\hline 10 & Denizbank & 70.1 & 92.1 & 94.7 & 92.9 & 82.8 & 77.7 \\
\hline 11 & Oyak Bank & 97.6 & 94 & 89.5 & 88.8 & 94 & 94.3 \\
\hline 12 & HSBC Bank & 63.2 & 89 & 91.3 & 56 & 65.1 & 75.3 \\
\hline 13 & Fortis Bank & 93.9 & 83.7 & 83.1 & 84.7 & 83.1 & 78.5 \\
\hline 14 & Turk Ekonomi Bankasi & 49.2 & 92.7 & 72.3 & 81.3 & 80.6 & 90.7 \\
\hline 15 & Sekerbank & 64.8 & 86.3 & 84.6 & 84.8 & 84.7 & 47.1 \\
\hline 16 & Citibank & 49.5 & 64.7 & 65.5 & 69.7 & 63.5 & 58 \\
\hline 17 & Anadolubank & 58.4 & 88.5 & 90.8 & 98 & 94.2 & 94.7 \\
\hline 18 & Tekstil bankasi & 79.2 & 69.1 & 89.4 & 89.6 & 90.2 & 91.9 \\
\hline 19 & Alternatif Bank & 85.4 & 76.2 & 84.8 & 86.3 & 93.4 & 95.3 \\
\hline 20 & ABN Amro Bank N.V & 96.4 & 52.5 & 89.9 & 70.3 & 71.6 & 74.2 \\
\hline 21 & Tekfenbank & 51.2 & 43.8 & 88.6 & 86 & 84.3 & 82.8 \\
\hline 22 & Turkish Bank & 64.4 & 55.4 & 60.8 & 79.4 & 72.1 & 69.6 \\
\hline 23 & MNG Bank & 89.1 & 53.5 & 79.6 & 89.1 & 89 & 94 \\
\hline \multicolumn{2}{|r|}{ Mean efficiency } & 77.7 & 81.457 & 86.965 & 86.226 & 86.652 & 84.352 \\
\hline
\end{tabular}


Table 7 Efficiency estimates of the Turkish banks according to ownership, Model 2

\begin{tabular}{|c|cccc|}
\hline Year & All banks & State-owned & Private & Foreign \\
\hline 2000 & $77.70 \%$ & $95.83 \%$ & $74.78 \%$ & $75.75 \%$ \\
2001 & $81.46 \%$ & $96 \%$ & $81.00 \%$ & $72.45 \%$ \\
2002 & $87 \%$ & $96.33 \%$ & $86.33 \%$ & $82 \%$
\end{tabular}

